\title{
8 \\ MEMBANGUN DESA \\ DENGAN KEARIFAN LOKAL \\ DI DESA PALAAN KECAMATAN NGAJUM KABUPATEN MALANG
}

\author{
Sri Handayani ${ }^{1}$, Mashur Hasan Bisri ${ }^{2}$ \\ ${ }^{1}$ Universitas Islam Raden Rahmat Malang \\ ${ }^{2}$ Universitas Islam Raden Rahmat Malang
}

Email:sh_katulistiwa@yahoo.com

\begin{abstract}
Abstrak
Penelitian ini bertujuan untuk membahas tentang pemanfaatan kearifan lokal (Local Wisdom) dalam pembangunan desa. Kearifan lokal yang sudah menjadi budaya lokal dan rutin dilaksanakan semuanya mengandung nilai-nilai norma, kesenian, gotong royong dan kebersamaan masyarakat perdesaan seperti; upacara adat, kegiatan kebudayaan, kegiatan keagamaan, dan kegiatan sosial masyarakat. Asas rekoqnisi dan subsidiaritas memberikan pengakuan dan kewenangan kepada desa untuk berdaya dan memandirikan dirinya. Undang-undang Nomor 6 Tahun 2014 tentang Desa adalah afirmatif kebijakan sehingga desa dapat melaksanakan berbagai macam bentuk pembangunan di semua. Pelaksanaan pembangunan memerlukan harmonisasi seluruh aspek masyarakat sehingga dapat memenuhi tahapan proses pembangunan, baik dari perencanaan, pelaksanaan, dan pertanggungjawaban. Evaluasi kebijakan pembangunan dapat dilakukan berdasarkan nilai-nilai luhur yang sudah berlangsung. Penelitian dilakukan dengan metode kualitatif. Pencarian data teknik wawancara untuk data primer dan mengakomodir data dan dokumentasi yang ada di desa untuk data sekunder. Hasil dari penelitian ini adalah peran kearifan lokal yang ada di Desa Palaan dengan berjalan pembangunan masyarakat Desa akan mempunyai hubungan yang sangat signifikan. Kearifan lokal yang bersifat kebudayaan seperti upacara adat dilakukan dalam rangka pra pelaksanaan kegiatan untuk pembangunan infrastruktur, bentuk kegiatan yang terdanai APBDesa adalah kelompok kesenian.
\end{abstract}

Kata Kunci : Kearifan lokal, kewenangan desa, pembangunan desa.

\begin{abstract}
This study aims to discuss the use of local wisdom in village development. Local wisdom that has become a local culture and is routinely implemented all contains norms, arts, mutual cooperation and togetherness in rural communities such as; traditional ceremonies, cultural activities, religious activities, and community social activities. The principle of recommendation and subsidiarity gives the village recognition and authority to be empowered and independent. Law Number 6 of 2014 concerning Villages is a policy affirmative so that villages can carry out various forms of development in all. The implementation of development requires the harmonization of all aspects of society so that it can fulfill
\end{abstract}




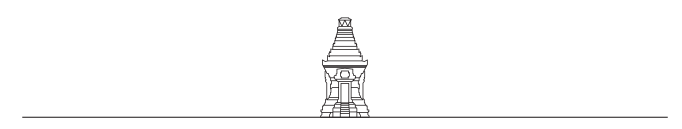

the stages of the development process, from planning, implementation and accountability. Evaluation of development policies can be carried out based on existing noble values. The research was conducted using qualitative methods. Data search interview techniques for primary data and accommodate existing data and documentation in the village for secondary data. The result of this research is the role of local wisdom in Palaan Village by running the village community development will have a very significant relationship. Local wisdom that is cultural in nature such as traditional ceremonies carried out in the framework of pre-implementation of activities for infrastructure development, the form of activities funded by APBDesa is art groups.

Keywords : Local wisdom, village authority, village development. 


\section{PENDAHULUAN}

Pemerintah Desa Palaan telah melaksanakan amanah Undang-Undang Nomor 6 Tahun 2014 Tentang Desa selama kurun waktu empat tahun. Pemerintah desa melaksanakan pembangunan di berbagai bidang mulai dari bidang pemerintahan desa, bidang penyelenggaraan pembangunan desa, Bidang pembinaan masyarakat desa, dan bidang pemberdayaan masyarakat desa. Ataupun Bidang lain-lain yang khusus atau tak terduga harus dilaksanakan. Selama empat tahun yang sudah dilalui, Desa Palaan telah melaksanakan dana desa dengan rincian sebagai berikut:

\begin{tabular}{l} 
Tabel 1.1 : Nilai Dana Desa Di Desa Palaan Tahun 2015-2018 \\
\begin{tabular}{|l|l|}
\hline Tahun & Jumlah Dana Desa \\
\hline 2015 & Rp. 279.815.000,- \\
\hline 2016 & Rp. 621.564.000,- \\
\hline 2017 & Rp. 873.320.000,- \\
\hline 2018 & Rp. 727.891.000,- \\
\hline 2019 & Rp. 835.808.000,-- \\
\hline
\end{tabular} \\
\hline
\end{tabular}

Dalam Undang-Undang Nomor 6 Tahun 2014 adalah sebuah entitas bagi desa dimana desa memiliki kewenangan penuh untuk mengurus dan mengatur rumah tangganya sendiri. Sehingga Desa menjadi sebuah wilayah yang otonom. Bahkan desa dapat menyebut dirinya tidak terdiskrimasi, menjadi maju, bahkan menjadi mandiri dengan cara memanfaatkan kucuran dana dari APBN, APBD, PAD, Berbagai macam sumber Bantuan Provinsi, mapun bagi hasil dan sharing hasil retribusi. Dimana semua bentuk pendanaan tersebut tercover dalam Anggaran dan Pendapatan Belanja Desa (APBDESA).

Menurut Antlov, Wetterberg, dan Dharmawan, 2016; Vel dan Bedner, 2015 dalam Irawan (2017:2-3) menyatakan bahwa untuk menanggulangi deskriminasi dalam Undang-undang Nomor 6 Tahun 2014, afirmasi kepada Desa ditunjukkan oleh adanya asas rekoqnisi dan subsidiaritas. Melalui asas rekoqnisi keberadaan desa diakui sesuai hak asal- usul, termasuk pengakuan terhadap desa adat. Sedangkan asas subsidiaritas menghormati kewenangan lokal di desa seluasluasnya sesuai dengan asal usul maupun adat yang masih berlaku.

Pada studi ini, akan melakukan pembahasan terhadap pembangunan desa yang mengarah pada konsep nasionalisme kebangsaan berdasarkan nilai-nilai kearifan lokal (local wisdom). Demikian halnya dalam kesenian tradisional yang mengarah pada konsep identitas lokal, sebagai bentuk dukungan kepada ketahanan nasional di bidang budaya. Penyelenggaraan budaya di masyarakat dapat diwujudkan melalui kegiatan berkesenian. Kesenian tradisional mengandung nilai-nilai kearifan lokal yang merupakan cerminan dari nilai-nilai Pancasila, sehingga nilai-nilainya akan menjadi budaya dalam suatu daerah dan dianggap dapat membentuk perasaan moral, membentuk perilaku, dan budi pekerti yang selanjutnya dapat menumbuhkan jiwa nasionalisme dan kebangsaan yang tangguh.

Mengingat Desa Palaan telah melaksanakan pembangunan sebagai implementasi dari Undangundang Desa selama kurun waktu lima tahun dengan total pendanaan senilai Rp.3.338.398.000,-. Maka studi ini akan mendiskripsikan proses evaluasi penggunaan anggaran Dana Desa dan semua penganggaran yang terekam dalam APBDesa tahun 2018 dalam pemanfaatan kearifan lokal sebagai daya dukung terhadap pembangunan.

\section{METODE}

Pendekatan yang digunakan dalam penelitian 
ini adalah pendekatan penelitian kualitatif. Jenis penelitian ini adalah studi kasus. Fokus penelitian kualitatif dimaksudkan untuk membatasi studi kualitatif, sekaligus membatasi peneliti dalam menentukan data yang relevan dan mana yang tidak relevan. Penelitian ini dilaksanakan di Kabupaten Malang dengan spesifikasi Lokasi penelitian ditentukan secara sengaja (purposive) yaitu di Desa Palaan Kecamatan Ngajum Kabupaten Malang. Penentuan sumber data dalam penelitian dilakukan sebagai upaya untuk mendapatkan data yang sebisa mungkin relevan dan akurat dengan harapan pembahasan penelitian ini sesuai dengan tujuan yang ingin dicapai.

Sumber data menyangkut pihak-pihak yang akan dijadikan narasumber tentang fenomena yang akan dijadikan sorotan dalam penelitian. Data primer, adalah data asli yang memuat informasi atau data yang langsung diperoleh dengan menggunakan pedoman wawancara (interview guide) dari sumber data atau informan, yaitu: pemerintah Desa Palaan yang diwakili oleh sekretaris Desa, Operator Sistem Keuangan Desa, dan komunitas budaya atau kesenian setempat. Data sekunder, adalah data pendukung yang diperoleh tidak secara langsung oleh informan. Bisa melalui dokumen, laporan-laporan dan sumber lainnya yang mempunya relevansi dengan obyek penelitian, yaitu data-data yang sudah tersedia di Desa Palaan, Kecamatan Ngajum, Kabupaten Malang.

\section{KAJIAN PUSTAKA EVALUASI KEBIJAKAN}

James E. Anderson (dalam Wahab, 2008a. Hal. 2) merumuskan kebijaksanaan sebagai perilaku dari sejumlah aktor (pejabat, kelompok, instansi pemerintah) atau serangkaian aktor dalam suatu bidang kegiatan tertentu. Selanjutnya Anderson menjelaskan bahwa "Public policies are those policies developed by governmental bodies and officials" (dalam Hill and Hupe, 2002: 5), yaitu bahwa kebijakan publik merupakan kebijakan yang dikembangkan oleh badan pemerintah atau pejabat pemerintah.

Namun menurut Charles O. Jones (lihat dalam Wahab, 2008a: 3) menyatakan bahwa kebijaksanaan itu ialah "a standing decision characterized by behavioral consistency and repetitiveness on the part of both those who make it and those who abide by it". Policy (kebijaksanaan/kebijakan) itu sebenarnya adalah suatu tindakan berpola yang mengarah pada tujuan tertentu dan bukan sekedar keputusan untuk melakukan sesuatu (lihat dalam Wahab, 2008a: 3). Berdasarkan teori yang dikemukakan Bromley dalam Tachjan (2006:17), kebijakan publik memiliki tiga tingkatan yang berbeda berdasarkan hierarki kebijakan, yaitu: policy level, organizational level, operational level.

Adapun dalam proses kebijakan publik merupakan serangkian kegiatan dalam menyiapkan, menentukan, melaksanakan serta mengendalikan kebijakan. Efektivitas suatu kebijakan publik ditentukan oleh proses kebijakan yang melibatkan tahapan-tahapan dan variabel-variabel. Dunn (1999: 22) mengemukakan aktivitas politis sebagai proses pembuatan kebijakan dan divisualisasikan sebagai serangkaian tahap yang saling bergantung yang diatur menurut urutan waktu: penyusunan agenda, formulasi kebijakan, adopsi kebijakan, implementasi kebijakan, dan penilaian kebijakan.

Menurut pendapat yang dikemukakan Jones (1996) secara umum menjelaskan evaluasi kebijakan sebagai suatu kegiatan atau aktivitas yang dirancang untuk menilai manfaat dari suatu kebijakan atau program pemerintah yang mencakup sub-sub kegiatan seperti spesifikasi obyek, Teknik pengukuran, metode analisis, dan rekomendasi yang dihasilkannya. Evaluasi Kebijakan juga dijelaskan oleh William N. Dunn (1999) sebagai sebuah tahapan kebijakan publik yang menempati 
posisi terakhir setelah implementasi kebijakan yang ditujukan untuk mengetahui apakah kebijakan yang telah dilaksanakan telah sesuai dengan harapan masyarakat dan terbukti efektif memecahkan permasalahan yang ada atau tidak. Melalui beberapa pengertian ini dapat disimpulkan bahwa evaluasi kebijakan publik adalah suatu aktivitas pasca dilakukannya implementasi kebijakan yang dirancang guna menilai kualitas dan manfaat dari kebijakan yang telah dilaksanakan.

Evaluasi merupakan bagian yang tidak terpisahkan dari sebuah kebijakan publik. Ia merupakan unsur yang penting dalam siklus kebijakan, sama pentingnya formulasi, dan implemetasi kebijakan. Oleh sebab itu kebijakan publik yang berkualitas hanya mungkin dicapai jika siklus itu mendapat perhatian seimbang, dalam hal formulasi, implementasi dan evaluasi kebijakan. Hal ini relevan dengan pendapat Dye (2002 : 45) bahwa evaluasi merupakan konsekwensi dari kebijakan publik. Sementara itu Winarno (2013: 93) menyatakan bahwa kebijakan publik adalah suatu proses yang rumit dan panjang, mempunyai tahap-tahap kebijakan yang tiada akhir, meskipun ada "terminasi", tetapi ada tahap-tahap berikut yang memungkinkan lahirnya "reformulasi" untuk melahirkan kebijakankebijakan baru. Siklus lahirnya kebijakan publik sampai pada lahirnya evaluasi juga diperkuat oleh Dunn (2003), Anderson (1990), dan Suharto (2010). Sebagai sebuah siklus, maka evaluasi kebijakan merupakan satu mata rantai yang tidak bisa dipisahkan satu sama lain. Itu sebabnya jika ada kebijakan yang kemudian dievaluasi, maka hal itu adalah hal yang biasa dan tentu menjadi bagian dari upaya untuk memperbaiki atau menyempurnakan kebijakan tersebut sesuai dengan tujuan yang ingin dicapai. Oleh karenanya Dye (1987:45) dalam Parsons (2008:545) mengemukakan bahwa evaluasi kebijakan sebagai pemeriksaan yang objektif, sistimatis, dan empiris terhadap efek dari kebijakan dan program publik terhadap targetnya dari segi tujuan yang ingin dicapai.

Kebijakan publik yang tidak tercapai sesuai dengan tujuan karena mengalami resistensi, maka hal ini akan menjadi salah satu mengapa suatu kebijakan perlu dievaluasi, apa penyebabnya dan bagaimana solusi yang harus diambil, apakah kebijakan itu harus dihentikan, dilakukan terminasi atau melaksanakan reformulasi untuk mendapatkan kebijakan baru. Dari realitas itu sehingga Parsons (2008: 545) menyebut bahwa evaluasi mengandung dua aspek yang saling terkait. a) Evaluasi kebijakan dan kandungan programnya b) Evaluasi terhadap orang-orang yang bekerja di dalam organisasi yang bertanggung jawab untuk implementasi kebijaan dan program. Selanjutnya Lester dan Stewart (2000:125). mengemukakan bahwa evaluasi suatu kebijakan dapat dibedakan ke dalam dua tugas yang berbeda, pertama adalah menentukan konsekwensi-konsekwensi apa yang ditimbulkan oleh suatu kebijakan, ini dilakukan dengan cara memberi gambaran apa dampak yang ditimbulkan kebijakan tersebut.

Selanjutnya yang kedua adalah mengevaluasi keberhasilan dan kegagalan suatu kebijakan berdasar pada standar atau kriteria yang telah ditetapkan sebelumnya. Tugas pertama merujuk pada usaha melihat apakah program kebijakan publik mencapai tujuan atau dampak yang diinginkan ataukah tidak. Bila tidak, apakah, apakah faktor-faktor yang menjadi penyebabnya. tugas kedua adalah evaluasi kebijakan yang pada dasarnya berkait erat dengan tugas yang pertama. Suatu evaluasi kebijakan menurut Jones, (1975 : 199) harus meliputi kegiatan, yakni penghususan (spesification), pengukuran (measurement), analisis dan rekomendasi. Specification merupakan kegiatan yang paling penting diantara kegiatan lain dalam evaluas kebijakan, Kegiatan ini meliputi identifikasi tujuan atau kriteruia melaluimana program kegiatn tersebut mau dievaluasi. 
Ukuran-ukuran kriteria ini yang akan dipakai untuk menilai apakah manfaat program. Pengukuran menyangkut aktifitas pengumpulan informasi yang relevan denga objek evaluasi, sedangkan analisis adalah penggunaan informasi yang telah terkumpul dalam rangka menyusun kesimpualn, dan akhirnya rekomendasi yakni penentuan mengenai apa yang harus dilakukan dimasa mendatang.

\section{KEARIFAN LOKAL}

Secara etimologi menurut Ermawi (2009) "kearifan (wisdom) berarti kemampuan seseorang dalam menggunakan akal pikirannya untuk menyikapi suatu kejadian, obyek, atau situasi”. Sedangkan lokal berarti kejadian yang terjadi pada daerahnya. Kearifan lokal adalah pikiran positif manusia yang berhubungan dengan alam, lingkungan yang bersumber dari adat istiadat, nilai agama, petuah-petitih nenek moyang yang terbentuk oleh masyarakat sekitar. Warisan ini dijadikan sebagai alat kontrol di masyarakat dan sudah melembaga sehingga menjadi kebudayaan.

Dalam bahasa asing, "kearifan lokal dikonsepsikan sebagai "local wisdom" atau pengetahuan setempat "local knowledge" atau kecerdasan setempat "local genious". Kearifan lokal sama juga halnya dengan nilai budaya yang dipegang oleh masyarakat yang dijadikan sebagai pandangan hidup. Akan tetapi, walaupun masa sejarahnya nilai-nilai kearifan lokal menjadi senjata utama dalam bermasyarakat, seiring dengan waktu berjalan, mengalami juga perubahan. Dengan adanya keanekaragaman bangsa Indonesia, sehingga kearifan lokal pun ikut mengalami perbedaan juga. Suku Melayu terkenal dengan kearifan lokalnya dengan "lain lubuk lain ikannya, di mana bumi diinjak di situ langit dijunjung”.

Menurut Teezzi, Marchettini, dan Rosini yang dikutip oleh Hasbullah (2012), menjelaskan bahwa kearifan lokal ini terbentuk oleh tradisi dan agama. Bagi masyarakat, "kearifan lokal dapat ditemui dalam nyayian, pepatah, sasanti, petuah, semboyan, dan kitab-kitab kuno yang melekat dalam perilaku sehari-hari”. Perilaku tersebut, sudah tercermin dari kebiasaan hidup masyarakat yang telah berlansung dengan lama.

Menurut Sedyawati (2007: 382) mengemukakan bahwa, kearifan lokal hendaknya diartikan sebagai "kearifan dalam kebudayan tradisional". Soebadio (Wibowo, 2015: 16-17) memberikan pengertian kearifan lokal sebagai sebuah identitas atau kepribadian budaya sebuah bangsa yang menyebabkan bangsa tersebut mampu menyerap bahkan mengolah kebudayaan yang berasal dari luar/bangsa lain menjadi watak dan kemampuan sendiri. Suhartini (2009:1) mendefinsikan kearifan lokal sebagai sebuah warisan nenek moyang yang berkaitan dengan tata nilai kehidupan.dimana tata nilai kehidupan ini tidak hanya menyatu dalam bentuk religi, tetapi juga dalam budaya dan adat istiadat.

\section{NILAI-NILAI KEARIFAN LOKAL}

Definisi nilai menurut Nashihin (2015) adalah sesuatu yang berharga, sehingga menjadi patokan dalam kehidupan. Nilai memberi makna dalam hidup, sehingga memberi corak dalam perilaku manusia. William yang dikutip Armiah (2014) mengemukakan bahwa nilai merupakan "... What is desirable, good or bad beautiful or ugly". Sedang Light, Keller \& Colhoun memberikan batasan nilai sebagai berikut: "Value is general idea that people share about what is good or bad, desirable or undesirable. Value transcend any one particular situatio Value people hold tend to color their overall way of life".

Diantara nilai tersebut, kearifan lokal adalah budaya masyarakat yang telah diciptakan oleh 
nenek moyang dan menjadi warisan bagi anak cucunya dan sebagai alat kontrol tingkah laku masyarakat. Nilai - nilai yang dianggap sebagai alat kontrol sosial dianggap juga sebagai nilai agama yang menjadi pedoman bagi kehidupan manusia. Sedangkan nilai yang tidak sesuai dengan nilai keagamaan dianggap oleh masyarakat sebagai yang tidak bisa menghargai nilai. Nilai yang dijadikan patokan dari kearifan lokal di masyarakat, telah lama berevolusi dalam masyarakat maupun lingkungan dan sudah beberapa kali mengalami masa periode generasi ke generasi. (Hasbullah,2012).

Dengan adanya perubahan sosial di masyarakat, mengakibatkan kearifan lokal, hampir terlupakan oleh masyarakat saat ini dan hampir juga terlupakan oleh sejarah dalam kehadirannya. Zaman nenek moyang, kearifan lokal terbentuk oleh adat dan tradisi masyarakat, sehingga dapat dikatakan sebagai produk budaya. Zaman sekarang, kearifan lokal sudah hampir tidak dikenali oleh masyarakat bahkan dunia pendidikan saat ini, disebabkan oleh kearifan lokal telah tergantikan oleh pendidikan karakter.

Jika dilihat dari sejarah kearifan lokal, pendidikan karakter hampir sama maknanya dengan kearifan lokal. Karena, kearifan lokal kurang diperhatikan oleh dunia pendidikan kita, sehingga pendidikan karakter hadir dalam dunia pendidikan yang juga terdiri dari nilai. Jika dikaji lebih mendalam, bahwa pendidikan karakter adalah pendidikan yang mengajarkan nilai-nilai positif, agar nilai tersebut menjadi kepribadian dalam diri anak. Sedangkan kearifan lokal adalah warisan leluhur nenek moyang yang mengajarkan nilai-nilai positif juga, untuk diturunkan ke generasi ke generasi agar nilai tersebut dapat menjadi alat kontrol dalam dirinya. Untuk lebih jelasnya, coba kita perhatikan tentang pengertian kearifan lokal itu sendiri.

\section{PEMBAHASAN}

Desa Palaan terletak pada posisi $8^{\circ} 11^{\prime}-2^{\circ} 24^{\prime}$ Lintang Selatan dan $112^{\circ} 54^{\prime}-70^{\circ} 53$ Bujur Timur. Secara administratif Desa Palaan terletak di Kecamatan Ngajum Kabupaten Malang Provinsi Jawa Timur. Di sisi Selatan berbatasan dengan Desa Talangagung Kecamatan Kepanjen, sedangkan di sisi Timur berbatasan dengan Desa Ngasem Kecamatan Ngajum.

Total lahan desa Palaan adalah 246,10 Ha. Luas sawah adalah 105,10 Ha. Lahan kering adalah 141,00 Ha, yang terdiri dari 1). Lahan permukiman/pekarangan adalah 123,60 $\mathrm{Ha}, 2$ ). Tegal atau kebun adalah 8,60 Ha, 3). Lahan lainnya adalah 8,60 Ha (BPS: 2018). Desa Palaan terbagi di dalam 10 Rukun Warga (RW) yang tergabung di dalam 2 Dusun Palaan-Krajan dan Dusun Sukoyuwono yang masing-masing dipimpin oleh Kepala Dusun. Berdasarkan data administrasi Desa Tahun 2014, jumlah penduduk Desa Palaan adalah 3.406 jiwa, dengan rincian 1.699 laki-laki dan 1.707 perempuan. Jumlah penduduk ini tergabung dalam $938 \mathrm{KK}$.

Capaian mengenai status kemajuan Desa Palaan berdasarkan Dana Desa yang telah diterima, Desa Palaan di Tahun 2017 mendapatkan status Desa Berkembang dengan nilai Indeks Desa Membangun adalah 0,6608. Terdiri dari Indikator Lingkungan (IKL): 0,6000, Indikator Ekonomi (IKE): 0,6167, Indikator Sosial Kesehatan (IKS): 0,7657.

Gambar 1 : Nilai Indeks Desa Membangun Desa Palaan Tahun 2017

INDEK DESA MEMBANGUN TH 2017 DESA PALAAN Kec. Ngajum Kab. Malang

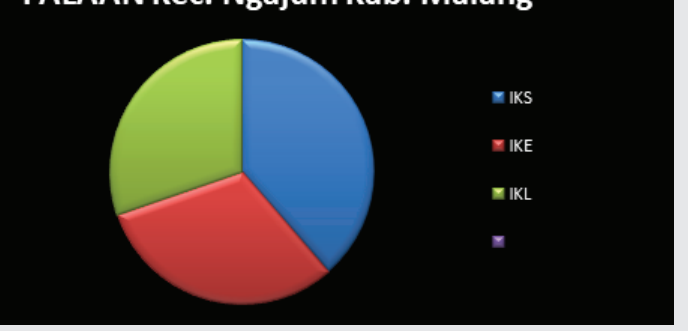


Penentuan status IDM pada Standar Operasional Prosedur (SOP) Pemutakhiran Status Perkembangan Desa Indeks Desa Membangun (IDM) (2018, hal:3) yaitu: dengan klasifikasi status desa yang ditetapkan dengan ambang batas sebagai berikut:

1. Desa Sangat Tertinggal : IDM $\leq 0,4907$

2. Desa Tertinggal : 0,4907 $<$ IDM $\leq 0,5989$

3. Desa Berkembang : 0,5989 $<$ IDM $\leq 0,7072$

4. Desa Maju : 0,7072 < IDM $\leq 0,8155$

5. Desa Mandiri : IDM $>0,8155$

Dari kategori yang ada diatas bahwa Desa Palaan merupakan salah satu Desa yang masih masuk kategori Desa Berkembang. Oleh karena itu dengan peran kearifan lokal (local wisdom) dalam pelaksanaan pembangunan akan mampu merubah tatanan, norma, nilai dan kultur masyarakat untuk menuju tahapan sebagai Desa Mandiri.

Berdasarkan analisa dan data di lapangan menemukan budaya masyarakat Desa Palaan yang selama ini menjadi tradisi yang di miliki masyarakat semenjak nenek moyang/leluhur mereka yang merupakan bagian dari kearifan lokal asli Di Desa Palaan, Kecamatan Ngajum, Kabupaten Malang, diantaranya adalah Tradisi Metik, Jaran Kepang, Pencak Silat, Punden Mbah Senthuaji ( Di Dusun krajan) Dan Mbah Suryati (Di Dusun Sukoyuwono), Bersih Desa, Banjari Tanjidor

Tradisi "metik"; tradisi yang dilaksanakan sebelum panen. Bagi masyarakat Desa Palaan yang sebagian besar berprofesi sebagai Petani, Tradisi metik ini telah menjadi adat/kebiasaan masyarakat Desa Palaan ketika mengawali menanam Padi, sebelum aktivitas panen dan memanen sebelum di mulai. Kita tahu masyarakat Desa Palaan sebagian besar menjalankan tradisi ini menjadi keyakinan mereka dan sebagai bentuk rasa syukur warga atas keberhasilan dalam bertani, terutama bercocok tanam padi. Sebagaimana yang hasil wawancara yang dilakukan peneliti terhadap salah Tokoh Masyarakat sekaligus sebagai Perangkat Desa Palaan yang bernama Supriyanto, mengatakan bahwa:

"Masyarakat Desa Palaan telah menjalankan tradisi adat sebelum menanam padi, sebelum aktivitas panen dimulai dan memulai panen tradisi kebiasaan warga desa melakukan ritual adat. Biasanya sebelum melakukan penananman padi mencari hari dan pasaran yang tepat, agar tanaman padi tersebut tumbuh dengan baik. Selain itu ketika aktivitas panen mau dimulai di lakukan uparaca ritual 'Tradisi metik panen' atau dalam bahasa jawanya dikenal dengan istilah 'ider-ider'. Tradisi metik ini dilakukan dengan membuat 4 sesajen kecil dan 1 sesajen besar. Dari 4 sesajen kecil ini diletakan di 4 sudut pojok sawah kiri dan kanan dan yang 1 sesajen besar diletakan di tengah. Biasanya ritual ini diiringi sambil bakar kemenyan dan membaca mantra-mantra jawa. Sehingga tradisi metik ini sebagai ungkapan rasa syukur atas panen padi" (wawancara tanggal, 15 September 2019).

Dari penjelasan di atas dapat diketahui bahwa tradisi metik panen yang terjadi di Desa Palaan merupakan tradisi dan adat, sekaligus keyakinan masyarakat yang dilakukan secara turun temurun sejak nenek moyang masyarakat. Dengan berjalannya waktu tradisi ini tetap di lestarikan secara terus menerus, sekaligus sebagai penopang utama secara adat untuk melakukan pembangunan Desa Palaan, terutama dalam sektor Pertanian yang menjadi sumber ketahanan pangan yang paling utama. Selama ini masyarakat Desa Palaan menikmati hasil panen padi sebanyak 2 kali dalam 1 tahun.

Jaran Kepang; Kesenian Jaran Kepang masyarakat Desa Palaan yang merupakan bagian dari tradisi kesenian dan budaya, masyarakat Desa Palaan. Kesenian ini menjadi bagian budaya yang sampai 
saat ini masih dilestarikan oleh masyarakat Desa Palaan, terutama para pemuda - pemuda Desa. Komunitas Kesenian Jaran Kepang ini berada di Dusun Sukoyuwono, Desa Palaan. Kesenian ini sampai saat ini masih menjadi kesenian yang dimiliki oleh masyarakat Desa Palaan secara umum, sebagaimana yang diungkapkan oleh Bapak Supriyanto sebagai warga Dusun Sukoyuwono, Desa Palaan mengatakan bahwa:

"Kesenian jaran kepang merupakan kesenian kebanggaan warga Desa Palaan. Sampai saat ini perangkat kesenian jaran kepang masih lengkap dan orang - orang yang menjalankan kesenian ii memiliki jiwa seni, sehingga ketika melakukan pertunjukan kelihatan baik. Kesenian ini biasanya dilakukan setiap bulan Suro dan terkadang juga setiap saat dilakukan pertunjukan sesuai keinginan warga masyarakat. Peran Pemerintah Desa Palaan terhadap kesenian ini begitu perhatian, sebagai bentuk pelestarian budaya masyarakat Desa yang setiap tahunnya mendapatkan anggaran dari Desa".

(Wawancara, tanggal 15 september 2019)

Dari penjelasan diatas dapat di analisis bahwa kesenian jaran kepang yang ada di Delaan merupakan kesenian lokal yang di miliki oleh Desa. Kesenian ini mempunyai peran yang penting dan menjadi kesenian yang asli yang di miliki masyarakat Desa. Sehingga dengan adanya arus modernisasi peran kesenian ini harus tetap dipelihara yang merupakan budaya asli milik warga Desa, terutama Desa Palaan. Oleh pemerintah Desa Palaan harus memberikan perhatian secara terus menerus, baik dari sisi anggaran maupun perhatian terhadap keberlangsungan kesenian tersebut untuk masa yang akan datang.

Pencak Silat; Budaya Pencak Silat biasanya dilestarikan oleh masyarakat di Desa Palaan, terutama oleh para pemuda yang menginjak usia remaja.
Dalam tradisi pencak silat ini di yakini sebagai aktifitas untuk melakukan pertahanan diri. Selama ini tradisi pencak silat yang sangat berkembang di Desa Palaan salah satunya Pencak Silat yang di gagas oleh Bapak Musaham (alm). Sebagai tokoh masyarakat Bapak Musaham (alm) dikenal sebagai seseorang yang Jago Silat pada waktu itu. Selanjutnya anggota pencak silat ini tidak hanya masyarakat Desa Palaan, banyak warga dari Desa lain yang tergabung dalam pencak silat ini dan untuk sekarang komunitas pencak silat ini diketuai oleh Bapak Joko Sakti, Seperti yang diungkapkan oleh Bapak Supriyanto, selaku warga Dusun Sukoyuwono, Desa Palaan mengatakan, sebagai berikut:

"Pencak Silat ini merupakan tradisi bela diri lokal yang ada di Desa Palaan. Dulu salah satu tokohnya adalah almarhum bapak Musaham. Beliau ini yang pertama kali mengembangkan tradisi bela diri Pencak Silat ini. Pencak Silat ini lahir di Dusun Sukoyuwono dan sampai sekarang jumlah pengikut pencak silat ini masih banyak. Dalam perkembangannya keberadaan pencak silat ini juga menjadi perhatian dari Pemerintah Desa Palaan, sehingga pencak silat ini sampai saat ini tetap berkembang”. (Wawancara tanggal, 15 September 2019)

Dari hasil wawancara diatas dapat diketahui bahwasanya masyarakat Desa Palaan memiliki tradisi pencak silat lokal yang sampai saat ini masih menjadi bagian budaya masyarakat Desa. Pencak Silat tersebut mempunyai jumlah anggota yang banyak dan bahkan juga berasal dari Desa-desa lain, selain dari Desa Palaan. Keberadaan pencak silat ini merupakan tanggungjawab pemerintah Desa Palaan untuk mengembangkannya dan setiap tahunnya mendapatkan anggaran dari pemerintah Desa melalui APBDes 
(Anggaran Pendapatan dan Belanja Desa).

Punden Mbah Senthuaji (di Krajan) dan Mbah Suryati (di Dusun Sukoyuwono) adalah Salah satu bentuk mengembangkan peradaban yang ada di wilayah pedesaan, diantaranya penghormatan yang tinggi terhadap leluhur yang ada di wilayah Perdesaan, yaitu: Melestarikan keberadaan Punden. Untuk Desa Palaan menurut cerita dari tokoh-tokoh masyarakat Desa mempunyai 2 (dua) Punden, terdiri dari Punden Mbah Senthuaji yang ada di krajan dan Punden Mbah Suryati yang ada di Dusun Sukoyuwono, Desa Palaan. Konon, menurut hasil cerita yang diperoleh dilapangan Punden kedua orang tersebut merupakan tokoh salah satu cikal bakal atau yang merintis Desa Palaan, Kecamatan Ngajum, Kabupten Malang. Sebagaimana yang di ungkapkan oleh Bapak Suriyanto, tokoh masyarakat Desa Palaan yang selalu "Nguri - Nguri" dari keberadaan Punden tersebut, yaitu:

"Dahulu pernah ada cerita dari tokoh masyarakat Desa Palaan bahwa Cikal bakal dari Palaan ini sebenarnya tidak bisa terlepas dari keberadaan punden tersebut. Punden Mbah Senthuaji, menurut ceritanya yang melakukan babad pertama kali yang berada di wilayah krajan, Desa Palaan. Sedangkan Punden Mbah Suryati yang melakukan babad pertama kali yang ada di Dusun Sukoyuwono. Dalam perkembangan kedua punden tersebut merupakan "Danyang" Desa Palaan yang saat ini menjadi bagian ritual masyarakat Desa Palaan. Sebagai penghormatannya warga desa terhadap punden tersebut selalu menjaga dan melestarikannya yang merupakan salah satu bentuk untuk menghormati dan menghargai leluhur yang berada di Desa Palaan". (Wawancara tanggal, 15 September 2019)

Dari wawancara tersebut diatas mengungkapkan bahwa Desa Palaan mempunyai 2 Punden utama, yaitu: Punden Mbah Senthuaji dan Punden Mbah Suryati. Peran dari kedua punden tersebut sangat besar terhadap perkembangan masyarakat Desa Palaan, sehingga menjadi satu kesatuan yang tidak bisa dipisahkan begitu saja oleh masyarakat Desa Palaan. Tradisi - tradisi ritual itulah yang biasa dilakukan oleh masyarakat Desa untuk mendoakan leluhur yang berada di kedua punden tersebut. Jadi sebagai masyarakat mempunyai peradaban, khususnya yang berada di Desa harus menjaga dan menghormati leluhur - leluhur atau nenek moyang yang berada di wilayah dengan melakukan sinergitas lahir dan batin dengan mengedepankan budaya dan tradisi lokal.

Bersih Desa (1 tahun sekali) adalah Kegiatan Bersih Desa ini merupakan sebuah tradisi/ kebiasaan yang dilakukan Pemerintah Desa Palaan. Bersih Desa ini bentuk kegiatannya tahlilan, pengajian dan kenduri bersama yang dilakukan warga Desa Palaan yang dilaksanakan di Punden Mbah Senthuaji yang ada di wilayah Krajan dan Punden Mbah Suryati yang ada di Dusun Sukoyuwono. Selain acara kenduri bersama, acara ini dilengkapi dengan kegiatan karnafal yang dilakukan oleh warga Desa Palaan, Kecamatan Ngajum, Kabupaten Malang. Salah satu cara melestarikan kebudayaan, khususnya tradisi orang Jawa bahwa Pertunjukan Wayang menjadi bagian yang tak terpisahkan masyarakat Desa Palaan. Tradisi wayangan biasanya dilakukan oleh Pemerintah Desa Palaan di bulan muharam atau 'Asyura. yang bersamaan dengan acara Bersih Desa Palaan. Menurut keyakinan masyarakat Desa Palaan pertunjukan wayangan ini sebagai salah satu bentuk ruwatan masyarakat Desa, agar mendapatkan keselamatan, sekaligus upaya untuk melestarikan kebudayaan Jawa. Seperti yang hasil wawancara yang dilakukan oleh peneliti terhadap Bapak Supriyanto, Sekretaris Desa Palaan, mengatakan bahwa: 
"Desa Palaan setiap tahunnya melakukan acara bersih desa dan biasanya dilakukan pada bulan suro dalam setiap tahunnya. Sedangkan puncak acaranya biasanya dilaksanakan pada hari senin legi. Kegiatannya dalam bersih desa meliputi pengajian, tahlilan, dan kenduri bersama yang di pusatkan di balai Desa Palaan. Selain itu masyarakat Desa Palaan secara umum dan bersama-sama melakukan ritual di punden mbah senthuaji dan di punden mbah suryati. Kemudian acara terakhir dengan menggelar wayang kulit semalam sampai dini hari. Dari agenda acara-acara tersebut sebenarnya sebagai bentuk untuk menyatukan kultur masyarakat Desa Palaan "Abangan" dan "Putih". Oleh karena itu moment bersih Desa Palaan sebagai wujud Persatuan masyarakat Desa Palaan”. (Wawancara tanggal 15 september 2019)

Dari hasil wawancara diatas menunjukan bahwa masyarakat Desa Palaan dan Pemerintah Desa Palaan dalam setiap tahunnya mempunyai agenda kegiatan utama, yaitu: Bersih Desa. Agenda yang diselenggarakan setiap tahun ini di inisiasi oleh Pemerintah Desa Palaan. Sehingga bersama Pemerintah Desa dan Masyarakatnya berkumpul menjadi satu untuk melakukan doa bersama dalam kelangsungan masyarakat Desa Palaan secara umum, baik dalam aspek spiritual maupun material dalam mencipkan masyarakat yang ikut membangun Desa dan Melestrarikan Budaya yang ada di Desa.

Banjari dan Tanjidor adalah Kesenian Banjari dan Tanjidor merupakan kebudayaan yang dimiliki masyarakat Desa Palaan yang sebagaian besar menganut agama islam. Banjari dan Tanjidor dilakukan oleh para pemuda yang tergabung dalam komunitas keagamaan dan biasanya dilakukan secara rutin dari rumah ke rumah secara bergiliran. Selain itu kesenian Banjari dan Tanjidor dilakukan ketika acara-acara tertentu yang berkaitan dengan keagamaan. Sebagaimana hasil wawancara dengan Bapak Supriyanto, salah satu tokoh kesenian Tanjidor, sebagai berikut:

"Kesenian religi banjari dan tanjidor ini sebenarnya merupakan kesenian khas Desa Palaan, misalnya kesenian tanjidor ini tradisi warisan leluhur secara turun temurun masyarakat, terutama yang berada di Dusun Sukoyuwono. Dari model peralatan dan syairsyair sholawat yang di lantunkan dari dahulu kala tidak mengalami perubahan sama sekali, demikian juga dengan peralatannya. Menurut cerita dari leluhur masyarakat sukoyuwono, kesenian tanjidor yang paling tertua yang ada di wilayah Desa dan sekitarnya”. (Wawancara tanggal , 15 September 2019)

Dari wawancara di atas bahwa di Desa Palaan yang sebagian masyarakatnya menjunjung tinggi tradisi budaya dan kesenian, terutama banjari dan tanjidor yang sampai saat ini masih kuat dalam kehidupan masyarakat merupakan salah satu dari peran yang di miliki oleh tokoh adat dan agama. Salah satu fungsi tokoh adat dan agama menjadi bagian penting yang ada di masyarakat Desa Palaan. Karen baik tokoh adat maupun tokoh agama oleh sebagian warga masyarakat sebagai orang yang di hormati atau selalu menjadi panutan/ tauladan masyarakat Desa Palaan.

Berikut adalah realisasi kegiatan terbang jidor di desa Palaan dapat dijelaskan melalui gambar berikut:

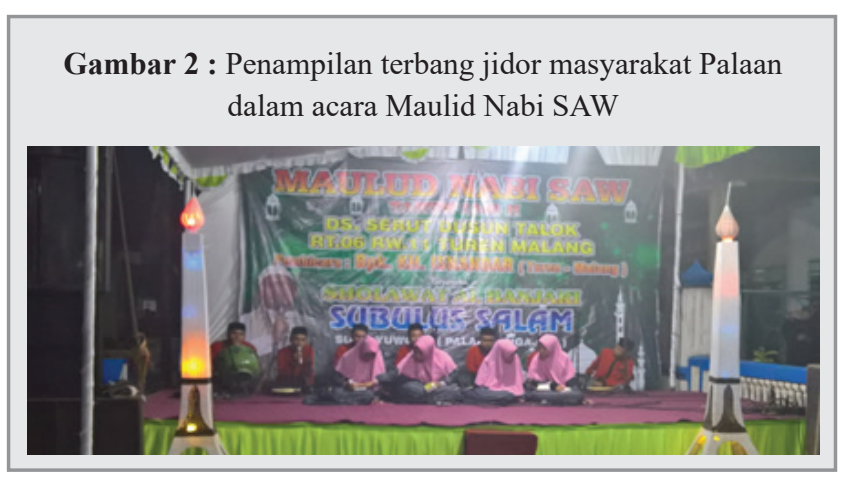




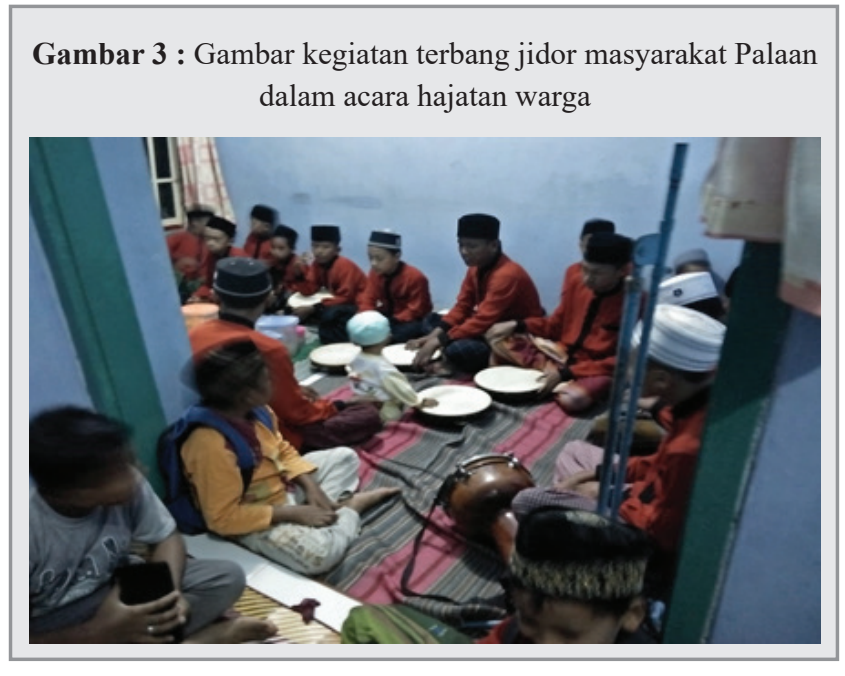

Dalam evaluasi penerapan kearifan lokal dalam pelaksanaan tahapan pembangunan desa pada tahap perencanaan pembangunan Desa yaitu: Rencana Pembangunan Jangka Menengah Desa (RPJMDESA) Desa Palaan, Rencana Kerja Pemerintah Desa (RKPDESA) 2018, dan Anggaran Pendapatan dan Belanja Desa (APBDESA) tahun 2018. Kegiatan yang berdasarkan kearifan lokal yang terdanai APBDESA Desa Palaan Tahun Anggaran 2018 adalah kegiatan Banjari Ali Mapan, Banjari Al Hikmah, Banjari Subbusalam PA, Banjari Subussalam PI, Terbang Jidor Al Hikmah, Terbang Jidor Al Arsy, Qosidah Asri Naada, Qosidah Al Mubarok, Kuda Lumping, Pencak Silat Sapu Jagat. Suatu evaluasi kebijakan menurut Jones, (1975:199) harus meliputi kegiatan, yakni penghususan (spesification), pengukuran (measurement), analisis dan rekomendasi. Specification merupakan kegiatan yang paling penting diantara kegiatan lain dalam evaluasi kebijakan, kegiatan ini meliputi identifikasi tujuan atau kriteria melalui mana program kegiatan tersebut dievaluasi.

Dalam kasus ini yang akan dievaluasi adalah penerapan kearifan lokal dalam pelaksanaan pembangunan Desa Palaan. Dari hasil penelitian di lapangan menemukan beberapa kearifan lokal yang ada di Desa Palaan. Menurut Sedyawati (2007) mengemukakan bahwa, kearifan lokal hendaknya diartikan sebagai "kearifan dalam kebudayan tradisional". Menurut Soebadio yang dikutip oleh Wibowo, (2015) memberikan pengertian kearifan lokal sebagai sebuah identitas atau kepribadian budaya sebuah bangsa yang menyebabkan bangsa tersebut mampu menyerap bahkan mengolah kebudayaan yang berasal dari luar/bangsa lain menjadi watak dan kemampuan sendiri.

Sedangkan menurut Suhartini (2009) men-

definsikan kearifan lokal sebagai sebuah warisan nenek moyang yang berkaitan dengan tata nilai kehidupan.dimana tata nilai kehidupan ini tidak hanya menyatu dalam bentuk religi, tetapi juga dalam budaya dan adat istiadat. Dari kedua teori tersebut sangat terkait dengan bentuk-bentuk kearifan lokal yang ada di Desa Palaan, diantaranya, yaitu: a). Tradisi metik panen yang terjadi di Desa Palaan merupakan tradisi dan adat, sekaligus keyakinan masyarakat yang dilakukan secara turun temurun sejak nenek moyang masyarakat. Dengan berjalannya waktu tradisi ini tetap di lestarikan secara terus menerus, sekaligus sebagai penopang utama secara adat untuk melakukan pembangunan Desa Palaan. Selama ini masyarakat Desa Palaan menikmati hasil panen padi sebanyak 2 kali dalam 1 tahun; b). Kesenian jaran kepang yang ada di Delaan merupakan kesenian lokal yang di miliki oleh Desa. Kesenian ini mempunyai peran yang penting dan menjadi kesenian yang asli yang di miliki masyarakat Desa. Sehingga dengan adanya arus modernisasi peran kesenian ini harus tetap dipelihara yang merupakan budaya asli milik warga Desa, terutama Desa Palaan.

Oleh karena itu pemerintah Desa Palaan harus memberikan perhatian secara terus menerus, baik dari sisi anggaran maupun perhatian terhadap keberlangsungan kesenian tersebut untuk masa yang akan datang; c). Desa Palaan memiliki tradisi pencak silat lokal yang sampai saat ini masih menjadi bagian budaya masyarakat Desa. 
Keberadaan pencak silat ini merupakan tanggungjawab pemerintah Desa Palaan untuk mengembangkannya dan setiap tahunnya mendapatkan anggaran dari pemerintah Desa melalui APBDes (Anggaran Pendapatan dan Belanja Desa); d). Desa Palaan mempunyai 2 Punden utama, yaitu: Punden Mbah Senthuaji dan Punden Mbah Suryati. Peran dari kedua punden tersebut sangat besar terhadap perkembangan masyarakat Desa Palaan, sehingga menjadi satu kesatuan yang tidak bisa dipisahkan begitu saja oleh masyarakat Desa Palaan. Tradisi - tradisi ritual itulah yang biasa dilakukan oleh masyarakat Desa untuk mendoakan leluhur yang berada di kedua punden tersebut. e). Desa Palaan dan Pemerintah Desa Palaan dalam setiap tahunnya mempunyai agenda kegiatan utama, yaitu: Bersih Desa. Agenda yang diselenggarakan setiap tahun ini di inisiasi oleh Pemerintah Desa Palaan.

Sehingga bersama Pemerintah Desa dan Masyarakatnya berkumpul menjadi satu untuk melakukan doa bersama dalam kelangsungan masyarakat Desa Palaan secara umum, baik dalam aspek spiritual maupun material dalam mencipkan masyarakat yang ikut membangun Desa dan Melestrarikan Budaya yang ada di Desa; f). Desa Palaan yang sebagian masyarakatnya menjunjung tinggi tradisi budaya dan kesenian, terutama banjari dan tanjidor yang sampai saat ini masih kuat dalam kehidupan masyarakat merupakan salah satu dari peran yang di miliki oleh tokoh adat dan agama. Salah satu fungsi tokoh adat dan agama menjadi bagian penting yang ada di masyarakat Desa Palaan.

Dari beberapa kearifan lokal yang ada di Desa Palaan tersebut mempunyai nilai-nilai. Definisi nilai menurut Nashihin (2015) adalah sesuatu yang berharga, sehingga menjadi patokan dalam kehidupan, misalnya tradisi metik panen yang di lakukan para petani Desa Palaan. Dalam tradisi metik panen mempunyai nilai yang memberi makna dalam hidup, sehingga memberi corak dalam perilaku manusia. Diantara nilai tersebut, kearifan lokal adalah budaya masyarakat yang telah diciptakan oleh nenek moyang dan menjadi warisan bagi anak cucunya dan sebagai alat kontrol tingkah laku masyarakat. Nilai-nilai yang dianggap sebagai alat kontrol sosial dianggap juga sebagai nilai agama yang menjadi pedoman bagi kehidupan manusia.

Sedangkan nilai yang tidak sesuai dengan nilai keagamaan dianggap oleh masyarakat sebagai yang tidak bisa menghargai nilai. Nilai yang dijadikan patokan dari kearifan lokal di masyarakat, telah lama berevolusi dalam masyarakat maupun lingkungan dan sudah beberapa kali mengalami masa periode generasi ke generasi, sebagai contoh budaya pencak silat Desa Palaan, Kesenian Jaran Kepang yang ada di Desa Palaan.

Jika dikaji lebih mendalam, bahwa pendidikan karakter adalah pendidikan yang mengajarkan nilai-nilai positif, agar nilai tersebut menjadi kepribadian dalam diri anak. Sedangkan kearifan lokal adalah warisan leluhur nenek moyang yang mengajarkan nilai-nilai positif juga, untuk diturunkan ke generasi ke generasi agar nilai tersebut dapat menjadi alat kontrol dalam dirinya. Untuk lebih jelasnya, coba kita perhatikan tentang pengertian kearifan lokal itu sendiri.

\section{KESIMPULAN}

Dari penjelasan diatas dapat disimpulkan mengenai perkembangan kebudayaan, adat dan tradisi kesenian yang merupakan kearifan lokal masyarakat di Desa Palaan, Kecamatan Ngajum, Kabupaten Malang. Sehingga jika dikaitkan peran kearifan lokal yang ada di Desa Palaan dengan berjalan pembangunan masyarakat Desa akan mempunyai hubungan yang sangat signifikan. Hal ini menjadi bagian dari keyakinan dan tradisi 
adat yang berkembang dimasyarakat selama ini, sehingga diperlukan pelestarian untuk kelanjutan yang akan datang, seiring semakin berkembangnya modernisasi yang cenderung merubah budaya dan tradisi original masyarakat pedesaan yang selama ini berbudaya secara turun temurun dari para nenek moyang atau leluhur masyarakat Desa.

Kearifan lokal yang bersifat kebudayaan seperti upacara adat dilakukan dalam rangka pra pelaksanaan kegiatan untuk pembangunan infrastruktur, sedangkan nilai-nilai yang terkadung dalam budaya tersebut belum mendapatkan porsi anggaran secara formal di APBDesa. Karena berbenturan dengan adanya system aplikasi pengelolaan keuangan desa yang terjadi dimana-mana. Kearifan lokal belum dianggap sebagai warisan peradapan yang dapat memberikan peran dalam aktifitas pembangunan, khususnya di Desa sehingga belum dapat mendukung pembangunan dikawasan perdesaan.

Seiring dengan berkembangan kebudayaan ditengah arus modernisasi hendaknya keberadaan budaya lokal tetap harus di pertahankan, bahkan perlu untuk dilestarikan secara berkelanjutan, karena merupakan warisan leluhur nenek moyang, terutama di Desa Palaan. Perlunya penambahan anggaran untuk mengembangkan adat dan budaya lokal masyarakat di Desa Palaan sesuai dengan porsi yang tepat. Oleh karena itu kedepan keberadaan kebudayaan lokal yang ada di Desa Palaan mendapatkan tempat yang memiliki nilai-nilai yang bersifat luhur.

\section{DAFTAR PUSTAKA}

Anderson, James E. 1990. Public Policy Making, An Introduction, Boston : Miftlin

Armiah, "Internalisasi Nilai-Nilai Keagamaan Lewat Media," Alhadharah, Vol.13, No. 25,2014, 2 .
Caroll Weiss, 1972. Evaluation Research, Englewood Cliffs, NJ. Prentice

Dunn, William N. 1999. Pengantar Analisis Kebijakan Publik, Gadjah Mada University Press, Yogyakarta.

Dye, Thomas R. 1981. Understanding Public Policy, Englewood Cliffs, Pentice - Hall, Inc. Dokumen Anggaran Pendapatan dan Belanja Desa Palaan Tahun Anggaran 2019 Faisal, Sanapiah. 1990. Penelitian Kualitatif: Dasar-dasar dan Aplikasi, Y A 3, Malang.

Hasbullah," Rewang: Kearifan Lokal dalam Membangun Solidaritas dan Integrasi Sosial Masyarakat di Desa Bukit Batu Kabupaten Bengkalis," Jurnal Sosial Budaya, Vol. 9, No. 2, 2012, 231- 232.

Imam Santoso Ermawi, Kearifan Lokal Dalam Perencanaan dan Perancangan Kota Untuk Mewujudkan Arsitektur Kota Yang Berkelanjutan (Malang: Group Konservasi Arsitektur dan Kota, Universitas Merdeka Malang, 2009).

Irawan, Nata, 2017, Tata Kelola Pemerintahan Desa Era UU Desa, Yayasan Pustaka Obor Indonesia.

Jones, Charles O, 1975. Clean Air, Pittsburgh, University of Pittsburgh Press.

Lester, James P, and Yoseph Stewart (2000). Public Policy : An Evolutionary Approach. Australia : Wodsworth, Second edition

Miles, M.B. \& Huberman, M.A. 1992. Analisa Data Kualitatif, UI-Press, Jakarta.

Moleong, Lexy J. 2007. Metodologi Penelitian Kualitatif. Bandung, PT. Remaja Rosdakarya. Nashihin, "Internalisasi Nilai-Nilai Agama Islam dalam Pembinaan Akhlak Mulia," Jurnal Ummul Qura, Vol. 5, No. 1, 2015, 2.

Parsons, Wayne, 2011. Public Policy : Pengantar Teori dan Praktik Analisis Kebijakan, Jakarta, Kencana.

Sedyawati, Edi. (2006). Budaya Indonesia, Kajian 
Arkeologi, Sejarah dan Seni. Jakarta: Penerbit Rajagrafindo Persada.

Suhartini," Kajian Kearifan Lokal Masyarakat Dalam Pengelolaan Sumberdaya Alam dan Lingkungan," Prosiding Seminar Nasional Penelitian, Pendidikan dan Penerapan MIPA (Yogyakarta: Fakultas MIPA, Universitas Negeri Yogyakarta, 2009), 206-208.

Wahab, Solichin A. 2008a. Analisis Kebijaksanaan dari Formulasi ke Implementasi Kebijaksanaan Negara, Bumi Aksara, Jakarta.

Winarno, Budi. 2013. Kebijakan Publik : Teori, Proses dan Studi Kasus, cetakan pertama, Edisi dan Revisi Terbaru, Yogyakarta. CAPS ( Center of academic Publishing Service). Wibowo, Agus \& Gunawan.(2015). Pendidikan Karakter Berbasis Kearifan Lokal di Sekolah. Yogyakarta: Penerbit Pustaka Belajar. 